\title{
Cuento: Sueños al lado del mar (1)
}

Short story: Dreams by the Sea (1)

\author{
Yael Ahava Angel \\ Empresaria Cultural Haifa Israel \\ yaelahava@gmail.com
}

\section{Artículo recibido el 24 de abril del 2016 \\ Aprobado el 02 de mayo del 2016}

Después de notar que yo estaba simultáneamente feliz y lúcido, una conjunción no sólo rara sino imposible, ella también quiso sentir lo mismo... Olía extrañamente a diminutas semillas de jazmín que hacían recordar mi viaje a la India en las últimas vacaciones de invierno. Tendida en el mismo lecho donde hicimos el amor, su espíritu se había dislocado de su pálida y helada piel y parecía extasiarse junto al mío, que estaba exultante por aquel gozo intempestivo y curioso.

Su ángel debía viajar después de tanto sufrimiento... ¡de tanto sufrimiento!

Recuerdo cuando conocí a Deborah. Estaba llorando mientras fumaba un cigarrillo en la esquina del puerto, ante la presencia de una esplendorosa tarde carioca. Tenía en su mano un papel con la condena de su muerte, sellada por el Hospital Central: el papelito del examen que confirmaba la agonía. Era la deuda que debía saldar mi necesitada mujer, dolores tras dolores, para poder así sentir su evolución en el tiempo que descontaban los segundos de su terminal escena.

Me sorprendí al ver que apenas tenía 20 años de edad. Desamparada, sin familia, criada en un orfanato donde el alimento era el pan seco que dejaban los marinos después de un viaje en alta mar.

Su hermosa pálida piel siempre la acompañó hasta su muerte. Sus labios incitaban profunda sensualidad y sus ojos azabaches eran la peregrinación que deleitaba mi procedencia. Un segundo más y mi sonrisa se enredó en sus dedos. - ¿Puedo sentarme? Llevo caminando varios kilómetros y estoy agotado, pero su belleza hace diluir el cansancio. 
-Sí señor. Siga, tome asiento.

Después de varias horas de contarnos la vida, la llevé a vivir conmigo, con toda la fortuna material que la banca me dejaba. Conocer a la mujer que doblegaría mis sueños era sellar el ciclo de una neurosis que empezaba a carcomer mi destino. Doblándole la edad a aquella perfecta adquisición, pude encontrar la mejor inversión de mi vida; y en el pasar del tiempo fui haciendo de aquella joven mi mayor tesoro, incluso sabiendo que iba desaparecer con el viento algún día.

Deborah aprendió a ser una gran dama. Su delicadeza, en las lecciones de etiqueta, la hacían desenvolverse con fluidez dentro de la exigente sociedad política y bancaría. Su calidez, agradable olor y sonrisa hicieron de mí el hombre más feliz de la existencia humana. El gusto por la buena mesa, sus capacidades por el buen arte y las reliquias de antigüedades que insistía en comprar dejaban ver que ella traía en su ser pasados de nobleza que se percibía sólo con observarla.

Sabiendo la gravedad de su enfermedad, contuvo su alma y me regaló dos hermosas niñas. ¡Aún no sé cómo se dio esta peligrosa hazaña! Debió ser por su fe, pues por ella regresé a mis raíces gracias a su insistencia de mantener la ley hebrea como cualquier madre judía. Mis hijas supieron seguir sus lecciones al pie de la letra en cada acontecer religioso. Meticulosamente, ellas hacen relucir en cada detalle los instantes de bendición en casa y sé que tendrán familias felices al lado de hombres piadosos que las valorarán.

-¡QQué miseria y qué soledad sin su presencia, que miseria!! La sed futura de mis pasos acabará por apagarme. Serán "los días" inmutables sin su aliento, ahí junto a mí... la muerte.

En el intento de vivir lo imposible, sus padres dieron a Deborah a la suerte; en la angustia de ser perseguidos, la madre llevó a la niña a un orfanato que se escondía en un túnel a las afueras de la ciudad. Mujeres de alta sociedad judías arrancadas de los brazos de sus importantes esposos médicos servían allí, escondidas en pánico y desolación.

Sarah, una de ellas, crio a Deborah con esmero, amor y disciplina, pero al pasar los años la vida se transformó en una dura y cruel realidad: Sarah falleció de una rara enfermedad, cosa que Deborah no pudo superar. La comida escaseaba y los agonizantes niños que fallecían por la inanición cada día eran más.

Así, mi esposa debió abandonar el lugar escondiéndose entre monasterios donde las novicias hacían la caridad de salvar vidas ocultando a las más desoladas jóvenes. Por cosas del destino fueron salvadas por cuerpos de rescate del gobierno brasilero, en las fronteras de un país europeo.

La comitiva decidió restablecer sus vidas en la maravillosa ciudad de Río de Janeiro. Miles de jóvenes judías y de niños volvieron a sonreír y construir la esperanza en ese majestuoso lugar. Un país multiétnico en donde una mujer exiliada, y condenada por ser judía, pudo ser feliz en los años que le quedaban y donde transformó un hombre -con una conjunción rara e imposible - en el más grande soñador, amándolo y construyendo con el sueños al lado del mar. 


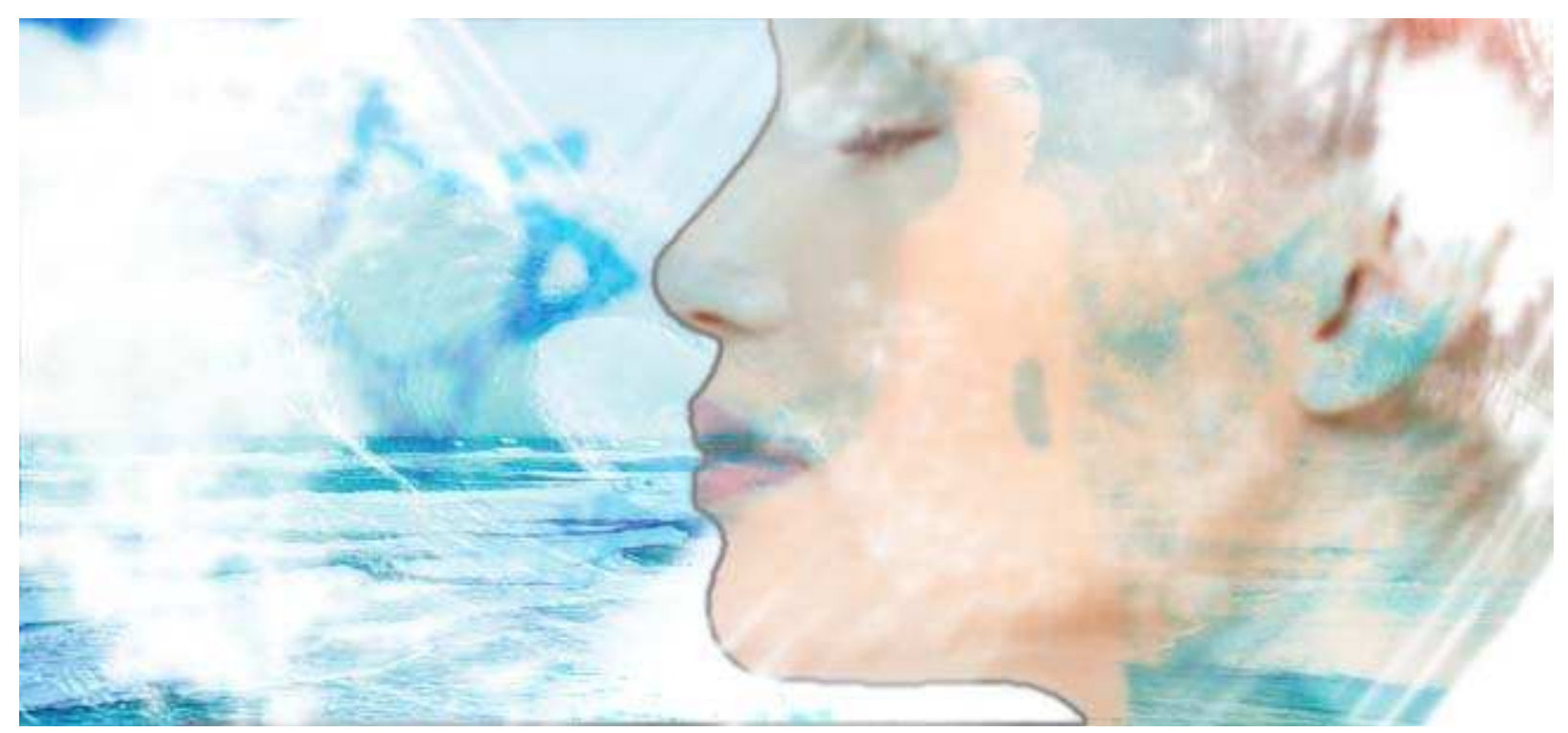

Nota.

(1). Citar este artículo como: Angel, Y. (2016) “Cuento: Sueños al lado del mar”. En: Revista La Tercera Orilla (16).

Bucaramanga: Universidad Autónoma de Bucaramanga 